\title{
IMPLEMENTASI LAYANAN BIMBINGAN KELOMPOK DENGAN MODEL $P B L$ UNTUK MENGURANGI KEBIASAAN SISWA MEROKOK DI SMK NEGERI 12 SURABAYA
}

\author{
Rika Hari Retnowati \\ SMK Negeri 12 Surabaya \\ rikaretnowati@yahoo.co.id \\ Sri Sutriswati \\ SMK Negeri 12 Surabaya
}

\begin{abstract}
Abstrak
Era millennial merupakan era penuh tantangan bagi guru bimbingan konseling dalam menghadapi perilaku siswa yang beragam. Perilaku siswa SMK yang paling muda kita temui yakni siswa yang telah terbiasa dengan merokok, Tujuan penelitian yaitu untuk mengetahui apakah implementasi bimbingan kelompok dengan metode Problem Based Learning dapat mengurangi kebiasaan merokok pada siswa. Subyek penelitian berjumlah 10 siswa Kelas XI jurusan Karya Kreatif Logam dan Perhiasan dengan metode pengumpulan datanya menggunakan dokumentasi, wawancara, dan observasi yang selanjutnya akan dianalisis menggunakan tindakan deskriptif kuantitatif dan analisis observasi. Hasil penelitian pelaksanaan layanan bimbingan kelompok dengan metode pembelajaran problem based learning dapat mengurangi kebiasaan siswa merokok.
\end{abstract}

Kata Kunci: Implementasi Bimbingan Kelompok, Metode PBL, Kebiasaan Siswa Merokok

\begin{abstract}
The millennial era is a challenging era for counseling guidance teachers in dealing with diverse student behavior. The behavior of the youngest vocational students we encounter is students who are accustomed to smoking, the purpose of this research is to find out whether the implementation of group counseling with the Problem Based Learning method can reduce smoking habits in students. The research subjects were 10 Class XI students majoring in Metal and Jewelery Creative Works with the data collection method using documentation, interviews, and observations which will then be analyzed using quantitative descriptive measures and analysis of observations. The results of research on the implementation of group counseling services with problem based learning methods can reduce students' smoking habits.
\end{abstract}

Keywords: Implementation of Group Guidance; PBL method; Student Habits of Smoking.

\section{PENDAHULUAN}

Era millennial merupakan era penuh tantangan bagi guru bimbingan konseling dalam menghadapi perilaku siswa yang beragam. Perilaku siswa SMK yang paling mudah kita temui yakni siswa yang telah terbiasa dengan merokok, bahkan sempat viral siswa salah satu SMK di Manado yang membunuh gurunya disebabkan siswa tidak terima ketika ditegur oleh guru tersebut ketika terdapati merokok dikelas. Perilaku merokok adalah perilaku yang massif di masyarakat saat ini terutama di kalangan pelajar SMK. Padahal setiap kandungan yang terdapat dalam rokok dapat merugikan bukan hanya pada diri si perokok sendiri namun juga merugikan orang lain yang ada di sekitarnya. Dari sisi kesehatan unsur-unsur kimia yang terkandung seperti nikotin, karbon monoksida dan tar, akan memacu kerja dari susunan saraf pusat dan susunan saraf simpatis sehingga mengakibatkan tekanan darah meningkat dan detak jantung bertambah cepat, menstimulasi kanker dan berbagai penyakit yang lain seperti infeksi tenggorokan, penyempitan pembuluh darah, jantung, paru-paru dan bronkitis kronis. Dari sudut kepribadian juga kurang pas, rata-rata siswa SMK merokok usia produktif, dan melanggar aturan sekolah serta menyalahi aturan dari Kementrian Kesehatan yakni usia perokok minimal 18 tahun. Dari sisi ekonomi merokok berarti mengeluarkan dana yang tidak perlu/menghambur-hamburkan uang. Selain kehilangan uang, juga harus membayar biaya kesehatan yang cukup besar karena rokok menyebabkan terjadinya berbagai macam penyakit.

Permendikbud No. 64 Tahun 2015 telah menyatakan Kawasan sekolah harus bebas dari rokok dan menurut Peraturan Pemerintah No.109 Tahun 2012, pasal 25 ayat b, tegas menyebut dilarang menjual produk tembakau kepada anak di bawah usia 18 tahun, namun yang terjadi di masyarakat siswa SMK yang notabene belum usia 18 Tahun sudah banyak merokok. bahkan berani merokok dengan menggunakan atribut seragam sekolah.

Mereka merokok tidak merasa akan dampak bahayanya rokok, mereka (perokok) dengan santainya merokok di depan sekolahan, dikendaraan umum dan 
tempat-tempat dimana banyak orang yang berlalu lalang. Padahal bahaya merokok tersebut tidak hanya berbahaya bagi perokok aktif, tetapi perokok pasif yang tidak merokok juga akan terkena dampak yang serupa bahayanya. Bahkan fenomena yang terjadi saat ini perilaku merokok sudah masuk ke lokasi sekolah, dilakukan pada saat pulang sekolah, berbeda dengan beberapa tahun yang lalu siswa merokok secara sembunyi-sembunyi karena takut dimarahi oleh orang tua maupun gurunya.

Meskipun pada awalnya siswa yang mencoba merokok kurang dapat menikmati rokok pertamanya karena membuat si perokok merasa pahit di mulut, mual dan pusing, namun karena dorongan sosial (dorongan teman-teman, lingkungan), perilaku pertama tersebut menjadi menetap. Perasaan mual dan pusing disebabkan karena tubuh memerlukan penyesuaian terhadap zat-zat yang terkandung di dalam rokok yang tidak dapat diterima tubuh, namun lama kelamaan menjadi terbiasa dan teradaptasi setelah mengalami beberapa kali percobaan merokok. Unsur-unsur yang terdapat di dalam rokok seperti nikotin dan karbon monoksida dapat membuat orang menjadi ketagihan dan ingin merokok lebih banyak lagi.

SMK merupakan tempat berlangsungnya pendidikan formal sudah selayaknya bebas dari asap rokok, karena salah satu wujud perilaku hidup sehat adalah tidak merokok baik secara pasif maupun aktif. Untuk mendukung perilaku hidup sehat tersebut, tiap SMK telah membuat tata tertib yang melarang siswa membawa apalagi merokok di lingkungan sekolah. Ini sesuai dengan program kementrian pendidikan di lingkungan sekolah harus bebas asap rokok tertuang pada Permendikbud No. 64 tahun 2015.

Pada kenyataannya di lingkungan sekolah masih belum bisa terbebas dari asap rokok, masih dijumpai beberapa staf TU dan beberapa guru yang masih mengkonsumsi rokok di lingkungan sekolah seperti halnya merokok di kantin. Yang lebih mengejutkan lagi berdasarkan angket ditemukan 90\% siswa kelas XI jurusan Karya Kreatif Logam dan Perhiasan SMK Negeri 12 Surabaya pernah mencoba merokok. 30\% pernah merokok di lingkungan sekolah. Berdasarkan buku catatan pelanggaran juga terdapat beberapa siswa yang ketahuan merokok di sekolah, membawa rokok dan korek api di sekolah serta sering menjumpai siswa putra merokok di luar sekolah.

Perilaku merokok siswa SMK Negeri 12 Surabaya biasanya muncul setelah kegiatan belajar di sekolah, ada beberapa kasus yang ditemukan siswa merokok di kantin sekolah dan kamar mandi. Tapi itu hanya sedikit siswa skitar 3 kasus yang ditemukan. Bukti perilaku merokok siswa paling banyak ditemukan di luar sekolah. Jika diprosentasekan ada lebih dari $30 \%$ siswa yang memiliki perilaku merokok.

Perilaku merokok siswa ini biasanya dipengaruhi beberapa hal antara lain: pengaruh teman, supaya dihargai di komunitas/teman sebaya, lebih percaya diri, rileksasi, merasa jantan, penghilang stres, serta kurangnya perhatian dari keluarga akan bahaya perilaku merokok bagi kesehatan. Siswa merupakan generasi penerus bangsa, oleh karena itu diharapkan memiliki pola hidup yang sehat sehingga muncul pemuda-pemimpin bangsa yang hebat, untuk itu pola hidup sehat merupakan persoalan penting dan mendesak untuk dicari penyelesaiannya.

Guru BK mempunyai tugas dalam membimbing serta membina siswa ke arah yang lebih baik, khusunya dalam kasus ini adalah perilaku kebiasaan merokok. Sudah beberapa upaya yang dilakukan dalam rangka memberi pengarahan kepada siswa yang kebiasaan merokok, terutama siswa putra telah dikenakan sanksi dan pemanggilan orang tua, serta memberikan layanan informasi dengan metode ceramah/klasikal di kelas sebagai upaya pencegahan, tetapi cara ini masih belum berhasil karena siswa kurang antusias dan masih belum memahami akan bahaya merokok bagi kesehatan sehingga masih ditemukan pelanggaran, kelemahan dari layanan ini adalah jumlah siswa yang terlalu banyak sehingga materi yang disampaikan kurang terfokus siswa.

Melihat banyaknya kasus tersebut, peneliti selaku guru bimbingan konseling mengupayakan beberapa langkah berkaitan dengan mengurangi kebiasaan siswa merokok, perilaku siswa yang anti rokok yaitu dengan menggunakan layanan yang terdapat dalam bimbingan dan konseling. Disini peneliti akan mencoba mengimplementasikan layanan yang bisa digunakan untuk membentuk perilaku mengurangi kebiasaan merokok adalah menggunakan layanan bimbingan kelompok dengan menggunakan metode problem based learning (PBL). Bimbingan kelompok adalah layanan yang membantu peserta didik mengoptimalkan dalam pengembangan pribadi, kemampuan hubungan sosial, kegiatan belajar, karir/jabatan, dan pengambilan keputusan, serta melakukan kegiatan tertentu melalui dinamika kelompok (Depdiknas, 2006).

Problem Based Learning (PBL) adalah metode pengajaran yang bercirikan dengan permasalahan nyata sebagai konteks untuk para peserta didik belajar berfikir kritis dan keterampilan memecahkan masalah, dan memperoleh pengetahuan (Duch,1995). Model pembelajaran berbasis masalah dilakukan dengan adanya pemberian rangsangan berupa masalah-masalah yang kemudian dilakukan pemecahannya oleh peserta didik. (Kemdikbud, 2013).

Metode pembelajaran berbasis masalah dipilih berdasarkan pada alasan utama yakni permasalahan yang 
muncul berkaitan dengan dampak bahaya dari perilaku kebiasaan merokok, sehingga metode pembelajaran berbasis masalah ini dipandang tepat untuk menumbuhkan sikap berhenti merokok pada diri siswa. Melalui metode pembelajaran ini, siswa diajak untuk berpikir bagaimana memecahkan permasalahan mereka agar mereka bisa berhenti merokok dan hidup dengan cara lebih sehat.

Rumusan penelitian ini yakni apakah dengan implementasi layanan bimbingan kelompok dengan metode $P B L$ dapat mengurangi kebiasaan merokok? Seberapa besar pengaruh layanan bimbingan kelompok dengan metode $P B L$ dalam mengurangi kebiasaan merokok pada siswa? Sedangkan tujuan dalam penelitian ini untuk mengetahui apakah implementasi layanan bimbingan kelompok efektif dengan metode $P B L$ dapat mengurangi sikap kebiasaan merokok pada siswa.

\section{METODE}

Penelitian ini menggunakan metode penelitian tindakan kelas (PTK). Peneliti lebih menyebutnya dengan PTBK sebab penelitiannya dalam ranah bimbingan konseling. Prosedur penelitian tindakan kelas menurut Suharsimi Arikunto (2009) model bagan penelitian tindakan secara garis besar terdapat 4 tahapan yang lazim dilalui yaitu (1) Perencanaan, (2) Pelaksanaan, (3) Pengamatan, dan (4) Refleksi.

PTBK ini dilaksanakan pada bulan Agustus sampai Oktober 2019 bertempat di SMK Negeri 12 Surabaya dengan subjek penelitian yaitu 10 siswa kelas XI jurusan Karya Kreatif Logam dan Perhiasan yang ratarata didominasi laki-laki yang kebiasaan merokok. Metode pengumpulan datanya menggunakan, angket, wawancara dan dokumentasi yang selanjutnya dilakukan triangulasi teknik dimana untuk menggali kebenaran informai tertentu melalui berbagai metode dan sumber perolehan data.

Peneliti menganalisis data penelitian tindakan bimbingan dan konseling melalui cara membandingkan antara data yang diperoleh pada saat kondisi awal sebelum diadakan tindakan, dibandingkan dengan data yang diperoleh setelah melalui tindakan pada siklus pertama dengan melalui tindakan pada siklus kedua, disebut juga dengan menggunakan tindakan deskriptif kuantitatif dan analisis observasi

\section{HASIL DAN PEMBAHASAN}

Berdasarkan hasil wawancara dengan subjek penelitian yang berjumlah 10 siswa diketahui bahwa ternyata siswa kurang paham mengenai dampak rokok, siswa juga kurang paham mengenai bahaya jangka panjang yang bisa ditimbulkan dari kebiasaan merokok, dan perilaku sikap merokok siswa dipengaruhi oleh faktor teman sebaya/lingkungan, dimana rata-rata temannya sudah pada merokok, dan mendapat celaan kalau tidak merokok, dan dengan merokok siswa menjadi percaya diri dan keliatan jantan.

Sedangkan dari hasil angket penelitian, nilai rata-rata yang diperoleh siswa masuk kategori rendah dengan ratarata 2,54, dalam kaitan kesadarannya untuk tidak merokok. Hasil wawancara sikap siswa untuk tidak merokok dapat di lihat pada Tabel 1 sebagai berikut:

Tabel 1. Hasil sikap siswa untuk tidak merokok pada Kondisi Awal

\begin{tabular}{lll}
\hline Kategori & Frekuensi & $\%$ \\
\hline Rendah & 7 & 70 \\
Sedang & 3 & 30 \\
Tinggi & 0 & 0 \\
\hline Jumlah & 10 & 100 \\
\hline
\end{tabular}

\section{Siklus I}

1. Perencanaan Tindakan

Tindakan pada siklus I direncanakan selama tiga pertemuan. Pertemuan dilakukan di ruang bimbingan kelompok dan dilaksanakan pada siang hari. Pertemuan pertama untuk menyusun jadwal pelaksanaan layanan bimbingan kelompok dengan metode pembelajaran Problem Based Learning, menentukan tempat untuk pelaksanaan tindakan, menyiapkan satuan layanan bimbingan kelompok, menyiapkan seluruh bahan dan skenario, pertemuan kedua melaksanakan layanan bimbingan kelompok dengan metode pembelajaran Problem Based Learning dan pertemuan ketiga membahas evaluasi dan tindak lanjut mengenai hasil yang dicapai.

\section{Pelaksanaan Tindakan}

Pelaksanaan tindakan pada siklus I, hampir sama dengan pelaksanaan layanan bimbingan kelompok pada umumnya, hanya yang membedakan pada penelitian ini adalah pada tahap kegiatan, dimana setelah tahap peralihan, siswa dikondisikan untuk berkelompok melaksanakan kegiatan pembelajaran Problem Based Learning, tahap-tahapan tersebut akan dijelaskan sebagai berikut :

a. Peneliti menanyakan kabar kepada anggota kelompok.

b. Peneliti menjelaskan tujuan dan tata cara pelaksanaan layanan bimbingan kelompok dengan metode Problem Based Learning. Tujuan metode pembelajaran ini yaitu untuk merangsang siswa agar peka terhadap masalah yang dihadapi dan mencoba mencari cara/solusi dalam menyelesaikan masalahnya, dalam hal ini adalah untuk tidak merokok.

c. Peneliti melakukan ice breaking untuk mencairkan suasana dan menyatukan anggota kelompok agar 
tercipta suasana yang kondusif untuk melakukan kegiatan bimbingan kelompok.

d. Peneliti menanyakan kesiapan anggota kelompok untuk memulai kegiatan bimbingan kelompok dengan teknik PBL.

e. Peneliti mengelompokkan siswa yang akan dijadikan subjek penelitian yaitu dikelompokkan menjadi 2 kelompok dari 10 siswa.

f. Peneliti mendefinisikan sebuah permasalahan, dan peserta didik melakukan berbagai kegiatan brainstorming dan semua anggota kelompok mengungkapkan pendapat, ide, dan tanggapan terhadap skenario secara bebas, sehingga dimungkinkan muncul berbagai macam alternatif pendapat tetapi masih dalam lingkup tema bahaya merokok bagi kesehatan serta bagaimana upaya yang bisa dilakukan untuk berhenti merokok. Salah satu kasus yang dimunculkan adalah tingkat kematian pengguna rokok aktif dan pasif yang semakin meningkat dari tahun ke tahun.

g. Semua anggota kelompok dipersilahkan mencari berbagai sumber yang dapat memperjelas isu yang sedang di investigasi. Sumber yang dimaksud dapat dalam bentuk artikel tertulis yang tersimpan di perpustakaan, halaman web, atau bahkan pakar dalam bidang yang relevan.

h. Anggota kelompok mengembangkan pemahaman mengenai materi yang dicari untuk dipresentasikan di dalam kelompok.

i. Setelah mendapatkan sumber untuk keperluan pendalaman materi dalam langkah pembelajaran mandiri, selanjutnya peserta didik berdiskusi dalam kelompoknya untuk mengklarifikasi capaiannya dan merumuskan solusi dari permasalahan kelompok. Kemudian kegiatan dilanjutkan ke tahap evaluasi dan refleksi mengenai kegiatan tersebut.

j. Pada tahap evaluasi ini, peneliti dan anggota kelompok membahas mengenai hasil yang dicapai pada kegiatan yang dilakukan, dan kemudian direfleksikan.

\section{Observasi}

Observermelakukan pengamatan terhadap 12 siswa yang kebiasaan mempunyai sikak merokok sedang dan melakukan observasi peneliti saat melaksanakan layanan bimbingan kelompok.

\section{Refleksi}

Berdasarkan hasil wawancara dengan angggota kelompok, observer dan catatan peneliti diperoleh sebagai berikut:

a. Keberhasilan peneliti, yaitu siswa menjadi mengetahui tentang rokok, dan siswa menjadi mengetahui mengenai bahaya yang bisa ditimbulkan dari perilaku merokok itu sendiri. b. Hambatan yang dihadapi peneliti, yaitu perilaku siswa merokok dipengaruhi faktor lingkungan, sehingga akan sangat sulit untuk merubah siswa karena faktor lingkungan mereka bermain tidak mendukung untuk bersikap tidak merokok.

c. Rencana perbaikan, peneliti merencanakan kembali melaksanakan layanan bimbingan kelompok dengan metode pembelajaran PBL.yang bertujuan menanamkan konsep diri mengenai sikapnya untuk tidak merokok, meskipun ada teman yang menawarkan untuk merokok, dengan cara memberi materi membandingkan perilaku merokok dengan perilaku pola hidup sehat. Tujuanya agar siswa bisa mengerti dan bisa membandingkan antara perilaku merokok dan perilaku hidup sehat dan siswa mampu memilih sikap mana yang akan dia ambil dan memberikan tampilan audio visual mengenai dampak bahaya yang bisa ditimbulkan dari perilaku merokok harapannya siswa menjadi sangat paham mengenai dampak yang bisa ditimbulkan dari bahaya merokok. Agar pelaksanaan kegiatan selanjutnya siswa lebih aktif dan antusias maka pelaksanaan layanan bimbingan kelompok dilaksanakan pada pagi hari, agar siswa masih semangat untuk melakukan aktivitas.

\section{Siklus II}

1. Perencanaan Tindakan

Pertemuan siklus II direncanakan 3 kali pertemuan dan kegiatan layanan bimbingan kelompok dilakukan pada pagi hari. Rencana tindakan pada siklus II pada dasarnya sama dengan siklus I, hanya ada perbedaan yaitu pelaksanaan layanan bimbingan kelompok dirubah dari siang hari dilaksanakan pagi hari agar lebih semangat mengikuti kegiatan, serta diadakan pembentukan kelompok tersendiri bagi siswa yang belum bisa bersikap tidak merokok dan dalam pemberian metode pembelajarannya ditambahkan media audio visual.

\section{Pelaksanaan Tindakan}

Pelaksanaan tindakan pada siklus II, hampir sama dengan pelaksanaan layanan bimbingan kelompok pada siklus I, hanya yang membedakan pada penelitian ini adalah penambahan inovasi yang membedakan dengan siklus I, agar hasil yang didapat pada siklus II lebih mendapatkan hasil yang memuaskan, inovasi tersebut adalah dengan pelaksanaan layanan bimbingan kelompok dirubah dari siang hari dilaksanakan pagi hari agar lebih semangat mengikuti kegiatan, serta diadakan pembentukan kelompok tersendiri bagi siswa yang belum bisa bersikap tidak merokok dan dalam pemberian metode pembelajarannya ditambahkan media audio visual. tahaptahapan tersebut akan dijelaskan sebagai berikut:

a. Peneliti menanyakan kabar kepada anggota kelompok. 
b. Peneliti menjelaskan tujuan dan tata cara pelaksanaan layanan bimbingan kelompok dengan metode Problem Based Learning. Tujuan metode pembelajaran ini yaitu untuk merangsang siswa agar peka terhadap masalah yang dihadapi dan mencoba mencari cara/solusi dalam menyelesaikan masalahnya, dalam hal ini adalah untuk tidak merokok.

c. Peneliti melakukan ice breaking untuk mencairkan suasana dan menyatukan anggota kelompok agar tercipta suasana yang kondusif untuk melakukan kegiatan bimbingan kelompok.

d. Peneliti menanyakan kesiapan anggota kelompok untuk memulai kegiatan bimbingan kelompok dengan teknik PBL.

e. Peneliti mengelompokkan siswa yang belum bisa merubah kebiasaan merokok dan yang sudah bisa mengurangi kebiasaan merokok.

f. Peneliti menayangkan sebuah tayangan bahaya merokok dan hidup sehat tanpa rokok kemudian semua anggota kelompok mengungkapkan pendapat, ide, dan tanggapan terhadap tayangan tersebut, sehingga dimungkinkan muncul berbagai pemahaman yang lebih mengena mengenai perilaku tidak merokok dengan yang merokok.

g. Anggota kelompok mengembangkan pemahaman mengenai materi yang ditayangkan untuk dipresentasikan di dalam kelompok kemudian kegiatan dilanjutkan ke tahap evaluasi dan refleksi mengenai kegiatan tersebut

h. Pada tahap evaluasi ini, peneliti dan anggota kelompok membahas mengenai hasil yang dicapai pada kegiatan yang dilakukan, dan kemudian direfleksikan

3. Observasi

Observer melakukan pengamatan kembali terhadap 10 siswa yang terbiasa merokok dan melakukan observasi peneliti saat melaksanakan layanan bimbingan kelompok.

4. Refleksi

Dari hasil wawancara oleh peneliti diperoleh hal-hal sebagai berikut:

a. Keberhasilan peneliti, yaitu dengan membandingkan perilaku merokok dengan perilaku tidak merokok ternyata mendapat hasil yang bagus, dimana siswa menjadi tahu di antara kedua perilaku tersebut mana yang baik, dan siswa menjadi tahu bahaya merokok secara nyata karena dengan bantuan audio visual. Selain itu adanya perubahan frekuensi merokok siswa juga menjadi bukti adanya keberhasilan dari penelitian ini.

b. Hambatan yang dihadapi, yaitu menanamkan konsep diri yang berkelanjutan kepada siswa agar siswa mampu menagkal perilaku merokok oleh dirinya sendiri.

Adapun perbandingan hasil pelaksanaan layanan bimbingan kelompok pada kondisi awal, siklus I dan siklus II dapat dilihat Tabel 2 sebagai berikut:

Tabel 2. Hasil Perbandingan Perubahan Sikap Tidak

Merokok (Kondisi Awal, Siklus I dan Siklus II)

\begin{tabular}{ccccccc}
\hline Kategori & Kond.Awal & \multicolumn{3}{c}{ Siklus I } & \multicolumn{3}{l}{ Siklus II } \\
\cline { 2 - 7 } & Frekuensi & $\%$ & Frekuensi & $\%$ & Frekuensi & $\%$ \\
\hline Rendah & 7 & 70 & 3 & 30 & 0 & 0 \\
Sedang & 3 & 30 & 5 & 50 & 6 & 60 \\
Tinggi & 0 & 0 & 2 & 20 & 4 & 40 \\
\hline Jumlah & 10 & 100 & 10 & 10 & 10 & 100 \\
\hline
\end{tabular}

\section{PENUTUP}

\section{Simpulan}

Simpulan menyajikan ringkasan dari uraian mengenai hasil dan pembahasan, mengacu pada tujuan penelitian. Berdasarkan kedua hal tersebut dikembangkan pokokpokok pikiran baru yang merupakan esensi dari temuan penelitian.

\section{DAFTAR PUSTAKA}

Arikunto, Suharsimi. 2009. Peneitian Tindakan Kelas. Jakarta: PT Bumi Aksara Depdiknas. 2005. Panduan Pengembangan Diri. Jakarta: Depdiknas

Becker, Jordy. 2008. Tips Cerdas Agar Anak Anda Berhenti Merokok. Jakarta : Prestasi Pustaka.

Hurlock, E.B. (2003). Psikologi Perkembangan. Jakarta: Erlangga.

https://www.tribunnews.com/regional/2019/10/26/siswasmk-di-manado-tikam-guru-agama-sampai-tewas-kpaiturun-tangan (di akses tanggal 24 Oktober 2019) https://gurudigital.id/model-pembelajaran-pbl-pengertianciri-ciri-kelebihan-kekurangan-langkah

(di akses tanggal 23 Oktober 2019) 